\title{
Renata Konieczna-Woźniak
}

Uniwersytet im. Adama Mickiewicza w Poznaniu

\section{Uczenie się jako strategia pozytywnego starzenia się}

\author{
Learning as a positive aging strategy
}

Streszczenie. Artykuł prezentuje problem uczenia się traktowany jak strategia pozytywnego starzenia się, zgodnie z koncepcją pozytywnego starzenia się Roberta D. Hilla. Rosnąca populacja osób starszych w Polsce generuje konieczność szukania kolejnych rozwiązań dotyczących tego, jak radzić sobie z podmiotowym i społecznym starzeniem się i starością. W Polsce, mimo pojawiających się dobrych praktyk, nadal brakuje systemowych rozwiązań w obszarze: opieki, służby zdrowia, aktywności zawodowej, aktywności kulturalnej i edukacyjnej kierowanych do osób starszych, a w szczególności najstarszych. Dominuje ekonomiczna perspektywa patrzenia na problemy starzejącego się społeczeństwa. Media promują młodość i konsumpcyjny styl życia, które nie sprzyjają pozytywnemu postrzeganiu starości i ludzi starszych. Uczenie się traktowane jest jako działanie strategiczne podejmowane dla pozytywnego starzenia się. Obejmuje ono trzy ważne komponenty: istotę uczenia się w starszym wieku, relację pomiędzy pozytywnym starzeniem się i uczeniem oraz uczenie się w sytuacji choroby i opieki długoterminowej. Uczenie się ludzi starszych oprócz nieocenionych korzyści dla samego podmiotu, podnosi produktywność społeczną i rozbudowuje kapitał społeczny starszego pokolenia.

Słowa kluczowe: pozytywne starzenie się, strategie pozytywnego starzenia się, uczenie się osób starszych, produktywność społeczna ludzi starszych

Summary. This paper presents the problem of older people's learning regarded as a positive aging strategy, according to the positive aging concept by Robert D. Hill. The growing population of older people in Poland generates the need to seek new solutions on how to deal with the subjective and social aging and the old age. In Poland, despite the fact that some good activities have been already emerging, there are still no system solutions in the area of : social welfare, health care, labor activity, cultural and educational activities targeted at the elderly, especially the oldest. What dominates is the economic perspective of looking at the 
problems of an aging society. The media promotes youth and consumerist lifestyles that are not conducive to positive perceptions of aging and older people.

Learning is treated as a strategic action taken for positive aging. It includes three important components: the essence of learning in old age, the relations between positive aging and learning, and learning in the case of illness and long-term care. The older people's learning in addition to the invaluable benefits for the person, increases the social productivity and expands social capital of the older generation.

Keywords: postitive aging, strategies for positive aging, older people's learning, social productivity of older people

\section{Wprowadzenie}

Społeczeństwo polskie, podobnie jak społeczeństwa innych krajów europejskich, starzeje się, a proces starzenia nabiera coraz większego tempa. $\mathrm{Na}$ podstawie prognoz demograficznych GUS eksperci ogólnopolskiego badania PolSenior informują, że odsetek ludności w wieku 65 lat i więcej będzie systematycznie wzrastał i w roku 2035 ma wynieść $23,2 \%$ z rozróżnieniem na wyższy udział osób starszych w miastach $24,3 \%$ i niższy na wsiach $21,7 \%$. Jeszcze bardziej jednoznaczne będą zmiany odsetka ludności w wieku 80 lat i więcej, ponieważ populacja tych osób w latach 2010-2035 zwiększy się ponad dwukrotnie, z 3,5\% do 7,2\%. Prognozuje się, że do 2035 roku udział osób w tej kategorii wiekowej w miastach wzrośnie do 8,1\%, podczas gdy na wsi osiągnie wartość 5,8\% (Błędowski 2012, s. 12-13).

Trzeba jednak zaznaczyć, że Polska przekroczyła próg demograficznej starości, tj. 7\% udziału osób powyżej 65 roku życia, już w latach siedemdziesiątych XX wieku, ale dopiero w XXI wieku zwrócono większą uwagę na rosnące przeobrażenia demograficzne, a w szczególności na ich konsekwencje. Polityka senioralna jest obecnie wyzwaniem lokalnym i globalnym. Inaczej przebiega starzenie się i starość w środowisku miejskim, inaczej w wiejskim, innymi zasobami i możliwościami dysponują konkretne regiony naszego kraju i sami ludzie starsi. Starość ma heterogeniczny charakter, ale mimo indywidualnych odrębności w przebiegu starzenia się i starości, polityka senioralna wymaga jednak też ogólnokrajowych rozwiązań.

W grudniu 2013 roku rząd polski przyjął założenia Długofalowej Polityki Senioralnej na lata 2014-2020. Twórcy tego projektu nazwali go pierwszym ogólnopolskim programem dla osób starszych. Zakłada on między innymi aktywne starzenie się w dobrym zdrowiu, większy udział osób starszych w życiu społecznym i solidarność międzypokoleniową. Program koncentruje się na ośmiu obszarach dotyczących różnych wymiarów życia senio- 
rów. Są nimi: zdrowie i samodzielność, aktywizacja zawodowa, aktywność edukacyjna, obywatelska, kultura, wolontariat, srebrna gospodarka. Minister pracy i polityki społecznej wprowadzając ten program polityki senioralnej podkreślił, że jego celem jest: „wspieranie seniorów w prowadzeniu w dalszym ciągu samodzielnego, niezależnego i satysfakcjonującego życia. Usuwanie przeszkód, które obecnie wykluczają osoby starsze z aktywnego życia społecznego". ${ }^{1}$

Problemy starszego pokolenia będą w kolejnych dekadach XXI wieku narastały, a polityka krajowa i regionalna będzie zmuszona radzić sobie z kolejnymi wyzwaniami związanymi ze starzejącym się polskim społeczeństwem.

\section{Aktualność tematyki gerontologicznej}

Zmiany demograficzne w Polsce spowodowały znaczące zainteresowanie przedstawicieli wielu dyscyplin naukowych problematyką gerontologiczną. W XXI wieku w obszarze psychologii, socjologii, pedagogiki, demografii, medycyny czy ekonomii oraz innych nauk, powstało bardzo dużo istotnych publikacji dotyczących starzenia się i starości oraz zorganizowano szereg konferencji naukowych o zasięgu krajowym i międzynarodowym.

Starość stała się też jednym z dość popularnych tematów w mediach. Tematem medialnym „wdzięcznym i niewdzięcznym” równocześnie. Z jednej strony chętnie podejmowanym, bo aktualnym i wielowątkowym, z drugiej trudnym, poważnym w świecie zarezerwowanym dla młodości. Wiadomości przekazywane w mediach, często wręcz straszą starością, wykorzystując chwytliwe, ale pełne dramaturgii i naznaczające ludzi starszych określenia. Retoryka dotycząca problemów starzenia się i starości zdarza się wręcz przerażająca. Spodziewamy się bowiem nadejścia: „demograficznego tsunami”, „dyktatu siwych głów”, „eksplozji starców na naszej planecie”, itp. zjawisk. Mogą one skutecznie straszyć tych, którzy jeszcze nie czują się starzy, a samych ludzi starszych wprowadzać w zakłopotanie, czy nawet prowokować ich samonaznaczanie, bądź inne praktyki autodyskryminacyjne.

Trzeba też zaznaczyć, że sami przedstawiciele mediów masowych dostrzegają polaryzację treści prezentowanych materiałów dotyczących starości i ludzi starszych. W mediach publicznych z jednej strony ukazywane są dramaty życiowe konkretnych starszych ludzi oraz zagrożenia wynikające

1 Wypowiedź ministra pracy i polityki społecznej Władysława Kosiniak-Kamysza http://www.mpips.gov.pl/aktualnosci-wszystkie/seniorzy/art,6535, nowa-polityka-senioralna-.html (otwarty: 27.12.2013) 
z przyrostu populacji seniorów dla innych grup wiekowych, z drugiej ckliwo-nostalgiczne, czy nawet czasami infantylne obrazy z życia ludzi starszych². W roku 2012 media silnie eksponowały też problemy ekonomiczne starszego pokolenia, w kontekście konieczności przedłużenia aktywności zawodowej i późniejszego przechodzenia Polaków na emerytury. Kultura konsumpcyjna natomiast stworzyła idealny obraz współczesnego człowieka, który powinien być młody, piękny i mobilny. Tym samym w mediach ludzie starsi mogą najczęściej odnaleźć swoje miejsce, wtedy gdy spełnią kilka warunków: podejmą walkę ze starością, będą bardzo aktywni, włączą się do grupy wiodących konsumentów i zrobią wszystko, by zatuszować własną metrykę.

Zarysowując jedynie aktualność i złożoność tematyki starzenia się i starości trzeba zwrócić uwagę na jeszcze jeden istotny fakt. W marcu 2013 roku, ogłoszono Indeks Aktywnego Starzenia się, będący wynikiem badań nad aktywnym starzeniem się w 27 krajach europejskich (Active Ageing Index 2013). Ocenie podlegała aktywność osób starszych w czterech obszarach:

1. zatrudnienie (w kategoriach wieku 55-59; 60-64; 65-69; 70-74)

2. aktywność społeczna (udział w wolontariacie, opieka nad dziećmi, opieka nad wnukami, opieka nad osobami starszymi, udział w życiu politycznym)

3. niezależność, zdrowie i bezpieczeństwo w życiu (niezależność finansowa, aktywność fizyczna, dostęp do usług medycznych, całożyciowe uczenie się, bezpieczeństwo zamieszkania)

4. przygotowanie otoczenia do wykorzystania szerokorozumianych zasobów (potencjału) starzejącego się społeczeństwa (oczekiwana długość życia, oczekiwana długość życia w zdrowiu, dobrostan psychiczny, korzystanie $z$ nowoczesnych technologii IT, relacje $z$ innymi ludźmi, poziom formalnego wykształcenia).

Polska w ogólnym rankingu znalazła się na ostatnim, 27 miejscu. Pierwsze miejsce zajęła Szwecja, drugie Dania, trzecie Irlandia. Analizując poszczególne domeny brane pod uwagę w badaniu, można dostrzec, że najsilniejszy nacisk położony został na aktywność społeczną i wykorzystanie potencjału ludzi starszych. Mają one oczywiście służyć seniorowi, jego poczuciu przynależności do społeczeństwa, bezpieczeństwu, zapobieganiu ekskluzji społecznej, ale priorytetem jest raczej aktywność seniora służąca jego niezależności i ekonomicznej produktywności. Takie postrzeganie aktywnego starzenia

2 Wypowiedź przedstawicieli mediów uczestniczących w dyskusji panelowej: Medialne lustro starości, podczas międzynarodowej konferencji naukowo-szkoleniowej: Wyzwania współczesnej geriatrii i gerontologii, Poznań 22-23 listopada 2013. 
się wynika z rosnącej szybko populacji osób starszych i wydatków związanych z tym procesem. Indeks Aktywnego Starzenia się (AAI) jest bowiem narzędziem do pomiaru niewykorzystanego potencjału osób starszych do aktywnego i zdrowego starzenia się w różnych krajach. Mierzy wspomniany już poziom samodzielności, niezależności osób starszych, aktywność zawodową i społeczną oraz zdolność do aktywnego starzenia się.

Definicja Międzynarodowej Organizacji Zdrowia (WHO) z roku 2002 za aktywne starzenie się, uznawała „proces optymalizacji szans związanych ze zdrowiem, uczestnictwem i bezpieczeństwem, mający na celu poprawę jakości życia osób starszych" (Active Ageing: A Policy Framework 2002). Definicję tę charakteryzuje szerokie ujmowanie aktywności, nastawionej w głównej mierze na cel, jakim jest podnoszenie jakości życia samych seniorów. W tym ujęciu aktywnego starzenia się podkreślano dobitnie, iż aktywności nie należy kojarzyć wyłącznie z pracą zawodową czy kondycją fizyczną. Odnosi się ona bowiem do wszelkich sfer życia: społecznej, gospodarczej, kulturalnej, duchowej, czy obywatelskiej (WHO Global Report on Falls Prevention In Older Age, 2007).

$\mathrm{Z}$ ujęciem aktywnego starzenia się nakierowanego przede wszystkim na podnoszenie jakości życia samych seniorów koresponduje, moim zdaniem, definicja produktywności społecznej autorstwa: James Hinterlong, Nancy Morrow-Howell, Michael Sherraden, przywołana przez Piotra Szukalskiego, która wykracza zdecydowanie poza ekonomiczne ramy. Produktywnością społeczną, została bowiem nazwana każda aktywność, która wytwarza dobra i usługi, niezależnie czy jest opłacana czy nie, włączając w nią aktywności takie jak: prace domowe, opiekę nad dziećmi, wolontariat, pomoc rodzinie i bliskim (Szukalski 2012, s. 407). Tego typu zajęcia są produktywne, a człowiek starszy dzięki nim realizuje również własną potrzebę bycia użytecznym. Niemniej jednak i w ten sposób rozumiana szeroko produktywność społeczna wymaga ciągłego uczenia się, odnawiania kompetencji, bądź nabywania nowych. Wydaje się jednak, że wraz z coraz większymi nakładami finansowymi związanymi z rosnącą populacją ludzi starszych oraz kryzysem gospodarczym, w Polsce dominuje ekonomiczne podejście do produktywności i aktywnego starzenia się osób starszych.

W tak skomplikowanej sytuacji ekonomicznej i społeczno-kulturowej, życie paradoksalnie daje nam prezent w postaci potencjalnej możliwości dożycia coraz większej liczby lat. Ten podarunek ma jednak też wysoką cenę, którą może być niezbyt pomyślny koniec życia, wymagający opieki i wsparcia ze strony innych ludzi. Lekarze ten zależny, wymagający wsparcia, pomocy i opieki czas szacują na co najmniej kilka ostatnich lat życia człowieka. 
W Polsce brakuje szpitali geriatrycznych, lekarzy geriatrów, domów pomocy społecznej, ośrodków wsparcia i doradztwa dla seniorów oraz profesjonalnie przygotowanych opiekunów osób starszych, szczególnie tych najstarszych. Ponadto istnieje niewystarczająca oferta kulturalna i edukacyjna realizująca potrzeby starszego pokolenia. Sieć uniwersytetów trzeciego wieku i klubów seniora, choć bogata, to i tak jest zbyt mała, a ponadto działa jedynie w miastach i nie zaspokaja rosnących i zróżnicowanych oczekiwań osób starszych. Rynek pracy, nadal nie jest przygotowany na przyjęcie i godne traktowanie starszych pracowników.

Sytuacja osób starszych, a w szczególności tych, którzy dopiero zestarzeją się w Polsce oraz ich rodzin nie napawa optymizmem. Brakuje bowiem nadal systemowych rozwiązań sprawowania opieki nad osobami starszymi i wspierania ich, szczególnie nad tymi najbardziej zaawansowanymi wiekowo, choć tak jak wspomniałam wcześniej, rząd zapowiedział na najbliższe lata długoterminowy program polityki senioralnej. W Polsce dotychczasowa polityka senioralna, promowanie aktywnego starzenia się obejmowało najczęściej osoby młode w grupie seniorów, czyli osoby w wieku 50 plus, czy nawet 45 plus. Mniej uwagi zwracało się na osoby w wieku 70, 80, 90, czy 100 plus. Określeniem senior obejmuje się bowiem osoby, których wiek metrykalny różni się nawet o 50 lat. W moim odczuciu, ta unifikacja też wymaga podjęcia dyskusji i konkretnych działań w wymiarze globalnym.

Obecnie w Polsce nie ma jeszcze dobrych, systemowych, ogólnokrajowych rozwiązań, nie oznacza to jednak, braku podejmowania różnych prób i zrealizowanych już udanych projektów oraz działających dobrych praktyk. Zanim jednak zostaną wypracowane nowe systemowe rozwiązania warto wykorzystywać pomysły oddolne, nawet nieformalne, realizowane w mniejszych środowiskach życia ludzi starszych.

Opowiadając się za szerokim rozumieniem produktywności społecznej osób starszych oraz aktywnym starzeniem się, które oprócz korzyści ekonomicznych przynosi zyski samemu człowiekowi starszemu i jego najbliższym warto po raz kolejny spojrzeć na problem uczenia się osób starszych w perspektywie pozytywnego starzenia się.

\section{Czym jest pozytywne starzenie się?}

Wyniki badań gerontologicznych przekonują, że od naszego stylu życia w dużej mierze zależy proces starzenia się i przebieg starości. Istotna jest więc rola podmiotu w kształtowaniu przebiegu własnej starości. Ważna jest 
też umiejętność wykorzystania wszystkich możliwych zasobów, które zgromadził i posiada człowiek. Dla budowania takiego przekonania niezbędne są następujące dowody empiryczne:

- u ludzi istnieje silne zróżnicowanie przebiegu starzenia się

- żyjąc dostatecznie długo, ludzie doświadczają pogorszenia stanu zdrowia i obniżenia możliwości intelektualnych w wyniku starzenia się, co jest naturalnym fizjologicznym procesem, ceną ponoszoną za coraz dłuższe życie

- wykształcone osoby, dokonując pewnych wyborów dotyczących stylu życia, mogą jednak w pewnym stopniu ograniczać starty związane z wiekiem (za: Hill 2009, s. 28).

Pozytywne starzenie (ang. positive aging) zgodnie $z$ koncepcją opracowaną przez Roberta D. Hilla ${ }^{3}$, oznacza wykorzystanie przez człowieka dostępnych mu zasobów w celu zoptymalizowania doświadczenia starzenia się. Stawanie się człowiekiem starszym jest naturalnym, ale równocześnie wartościowym doświadczeniem. Do zasobów, które można wykorzystać, by starzeć się w pozytywny sposób należą:

- $\quad$ wrodzone predyspozycje psychiczne, które jednak w dużej części poddają się sile woli lub stanowi umysłu

- $\quad$ warunki środowiskowe (procedury medyczne, dostęp do usług medycznych i opiekuńczych, warunki mieszkaniowe, wykonywana praca, różne zajęcia, itp.)

- cechy indywidualne - osobowość, postawy, przekonania (Hill 2009, s. 42).

Najważniejszym założeniem koncepcji pozytywnego starzenia się R. D Hilla, jest moim zdaniem, teza mówiąca o tym, że człowiek może wpłynąć na przebieg starzenia się niezależnie od deficytów, które pojawiają się w trakcie biegu życia.

Pozytywne starzenie się jest koncepcją powiązaną z pomyślnym starzeniem się, , ale zakorzenioną silniej w innym, młodszym nurcie psychologicznym - psychologii pozytywnej. R. D. Hill uznaje bowiem te same cechy, cnoty, przymioty człowieka, co Martin E.P. Seligman (jeden z twórców psychologii pozytywnej), za ważne i pełniące funkcje ochronne w zmaganiu się z trudnościami codziennego życia. Należą do nich: odwaga, nastawienie

3 Robert D. Hill jest licencjonowanym psychologiem, terapeutą, profesorem psychologii na Uniwersytecie Utah.

4 Definiowanie pomyślnego starzenia się i uporządkowanie zróżnicowanych jego koncepcji można znaleźć w wielu publikacjach, między innymi w: Halicki 2006, 2008, 2010, Zając-Lamparska 2012. 
na przyszłość, optymizm, zdolności interpersonalne, wiara, etyka pracy, nadzieja, uczciwość, zdolność zaangażowania i wnikliwość (Hill 2009, s. 42, za: Seligman, Csikszentmihalyi 2000; Seligman 2005; 2011). Pozytywne starzenie się, podobnie jak szczęście (w psychologii pozytywnej), jest konstruktem psychologicznym, określonym stanem umysłu, ale też tak samo konkretną formą działania, strategią. Stąd, żeby starzeć się pozytywnie, trzeba włożyć w ten proces sporo pracy i wysiłku. (Hill 2009, s. 16).

Z punktu wiedzenia andragogiki, pedagogiki czy też gerontologii społecznej najważniejszym założeniem pozytywnego starzenia się, moim zdaniem, jest to, że człowiek może wpłynąć na przebieg procesu starzenia. Pozytywnego starzenia się powinniśmy zaczynać się uczyć zanim staniemy się starzy.

Ważne jest również, że koncepcja pozytywnego starzenia podkreśla, iż stawanie się człowiekiem starym jest wartościowym doświadczeniem, jednak aktywne kształtowanie procesu starzenia się, wymaga sporej wewnętrznej dyscypliny i własnej pracy podmiotu. Ponadto zwraca uwagę, na nieuchronność strat, konieczność śmierci, jako naturalnych elementów cyklu życia. Skupia się jednak silniej na działaniach mogących zwiększać dobrostan człowieka, nawet przy pogarszaniu się zdrowia i zachodzących niekorzystnych wpływach środowiska życia. Dla pozytywnego starzenia się charakterystyczne są następujące cechy, na podstawie których, można określić, czy ktoś stara się starzeć pozytywnie. Moim zdaniem są to równocześnie konkretne, świadomie podejmowane działania:

- mobilizacja posiadanych zasobów, potencjału, aby radzić sobie ze związanym $z$ wiekiem pogarszaniem się stanu zdrowia, poprzez stosowanie technik asymilacji i akomodacji

- dokonywanie wyborów dotyczących stylu życia, w taki sposób, aby zachować dobrostan psychiczny

- dbałość o elastyczność w całym okresie swojego życia. Dzięki tej bazowej umiejętności, człowiek potrafi adaptować się do pojawiających się w życiu zmian, poszukuje pomocy i porad, jeśli nie radzi sobie sam, nie unika potrzebnej mu pomocy

- skupianie się na pozytywnych stronach życia, a nie na problemach i trudnościach związanych ze starością. Człowiek potrafi mieć dystans do trudności, bo one zdarzają się zawsze w życiu, są jego częścią (Hill 2009, s. 44-52).

R. D. Hill w swojej koncepcji pozytywnego starzenia się proponuje siedem strategii, a każda z nich wymaga zastosowania wcześniej wyróżnionych działań. Strategiami pozytywnego starzenia się są: odnajdywanie sensu starszego wieku, uczenie się niezależnie od wieku, wykorzystywanie prze- 
szłości po to, by kształtować mądrość, pielęgnowanie długotrwałych relacji międzyludzkich, wspieranie osobistego rozwoju poprzez dawanie i otrzymywanie pomocy, wybaczanie sobie i innym, posiadanie wdzięcznego stosunku do życia (Hill 2008).

Uczenie się możliwe jest w każdym wieku, takie przekonanie buduje jedną z ważniejszych strategii pozytywnego starzenia się R. D. Hilla, który wyraźnie podkreśla: „nigdy nie jesteś za stary, żeby się uczyć” (Hill 2008, s. 23).

\section{Wiek człowieka nie musi stanowić bariery w uczeniu się}

W środowisku andragogów i gerontologów społecznych powszechnie znany jest raport Jacqes'a Delorsa z lat 90.: „Edukacja - jest w niej ukryty skarb”. Moim zdaniem ten wymowny tytuł szczególnego znaczenia nabiera wtedy, gdy podejmujemy temat edukacji osób starszych. Uczenie się w późniejszym wieku stwarza bowiem nowe możliwości rozwoju.

R. D. Hill analizując problem uczenia się osób starszych dostrzega w nim trzy ważne kwestie: sens uczenia w późniejszym wieku, relację pomiędzy pozytywnym starzeniem się i uczeniem się oraz uczenie się w sytuacji choroby i opieki długoterminowej.

\section{SENS UCZENIA SIĘ OSÓB STARSZYCH}

Istotę uczenia się $\mathrm{w}$ starszym wieku oddaje wymownie cytat zaczerpnięty przez R. D. Hilla, z wypowiedzi znanego amerykańskiego przedsiębiorcy i ekonomisty XX wieku Henry Forda: „Każdy, kto przestaje się uczyć jest stary, nieważne, czy ma dwadzieścia czy osiemdziesiąt lat. Każdy, kto ciągle się uczy jest młody. Najwspanialszą rzeczą w życiu jest mieć młody umysł" (Hill 2008, s. 23).

Zdaniem R. D. Hilla obecnie za sprawą Internetu, radia, telewizji, nowoczesnych technologii informatycznych, możliwości uczenia się zostały mocno rozszerzone. Wiemy bowiem, że edukacja oprócz formalnego poziomu obejmuje również pozaformalny i nieformalny. R. D. Hill uważa, że nasze domy stały się współcześnie księgarniami, a wiedza ma wiele form i kontekstów. Niemniej jednak w społeczeństwie nadal pokutują stereotypy dotyczące uczenia się ludzi dorosłych. Trzeba jednak zauważyć, że w stereotypach może kryć się część prawdy, ponieważ starsi ludzie dorastali w innym systemie edukacyjnym, niż obecne młodsze pokolenia. Wcześniejszy system zakładał uczenie się według specyficznej tradycji i bazował na dość tendencyjnych założeniach. (Hill 2008, s. 24). 


\section{4 | Renata Konieczna-Woźniak}

Pierwszym z tych stereotypowych założeń było, że edukacja jest w głównej mierze zależna od wieku. Uważano, że uczenie się musi odbywać się w określonym miejscu i czasie i aby się uczyć trzeba być młodym. Uczenie tak pojmowane, nierozerwalnie wiązało się ze szkołą, z nauczycielem, z formalnym systemem edukacji. Lokowanie uczenia się w szkolnej klasie a kontroli i wsparcia w osobie nauczyciela, przy równocześnie dość pasywnej roli ucznia, nie odpowiada współczesnym ludziom dorosłym.

R. D. Hill podkreśla, to co dostrzegają również polscy andragodzy, że nowe podejście do uczenia się ludzi dorosłych skupia się między innymi na zróżnicowanych przestrzeniach edukacji i komforcie pracy edukacyjnej ucznia (Malewski 2010, Aleksander 2009; Matlakiewicz, Solarczyk-Szwec 2009; Solarczyk-Ambrozik 2009). Stąd trzeba zapewnić uczniowi możliwość koncentracji na przedmiocie nauki poprzez stworzenie mu jak najbardziej przyjaznego środowiska uczenia się. Oznacza to rozszerzenie nauki poza klasę lekcyjną i przeniesienie jej często do domu, czy też do miejsca grupy, osób które wspólnie uczą się.

Drugie z wcześniejszych stereotypowych założeń, zdaniem R. D. Hilla, wymagało od ucznia konieczności posiadania intelektualnych atrybutów ludzi młodych: wysokiego poziomu sprawności funkcji poznawczych, dobrej pamięci i uwagi. W szkole bowiem szczególnie przydane były i często są nadal: umiejętność czytania i pisania, szybkiego uczenia się i rozwiązywania testów szkolnych. Atrybutami dobrego ucznia są więc, zgodnie ze stereotypowym spojrzeniem na edukację: optymalne możliwości związane z rozwojem biologicznym, zdolność do szybkiego uczenia się i osobisty wysiłek. Jak wiadomo, pamięć i uwaga są najlepsze, kiedy jest się młodym, stąd powyższe przekonanie niestety ogranicza wiele dojrzałych wiekowo osób. Są bowiem przekonane, że są już „zbyt stare” na naukę. R. D. Hill podkreśla, powołując się na rozliczne wyniki badań, że w procesie uczenia się, oprócz procesów poznawczych, równie ważne są określone cechy osobowe, takie jak: poczucie wartości wiedzy, doświadczenie życiowe, dociekliwość, elastyczność i wybiórczość percepcji. Część z nich zyskujemy dopiero w podeszłym wieku. Dzięki temu starsi uczniowie mają szczególną zdolność do uczenia się (Hill 2008, s. 26).

Trzecie stereotypowe przekonanie dotyczy treści uczenia się i roli osoby kierującej procesem uczenia się. Znajomość zmian poznawczych mogących pojawić się wraz z wiekiem jest kluczowa dla nauczyciela dorosłych. W przypadku osób starszych, np. z zaburzeniami słuchu, motoryki, albo wzroku możliwe są problemy w uczeniu się, nawet jeśli posiadają ogólną zdolność do uczenia się. Uwzględnianie tych zmian w procesie uczenia się 
jest niezwykle ważne. Atutem osób dojrzałych wiekowo jest jednak to, że stawiają więcej pytań niż ludzie młodzi o cel, sens uczenia się. Zainteresowanie uczeniem się $\mathrm{w}$ starszym wieku wynika bowiem $\mathrm{z}$ konkretnych potrzeb życiowych. Starsi uczniowie potrzebują innych tematów $i$ innych środków nauczania aniżeli młodzi. Niektórzy ludzie starsi uczą się nawet lepiej niż młodsi, kiedy mają zapewnione więcej czasu na naukę i dogłębnie mogą poznawać materiał nauczania. Źle na nich wpływa presja czasu. R. D. Hill podkreśla, że nie zawsze jednak nauka ludzi dorosłych musi uwzględniać wyłącznie ich potrzeby praktyczne. Dla niektórych uczenie się jest bardzo autoteliczne, satysfakcjonujące, stanowi szansą, by nauczyć się czegoś nowego, choć nie jest już zobowiązaniem społecznym (Hill 2008, s. 27-28). Na ten sam problem zwraca uwagę Knud Illeris w swojej książce: „Trzy wymiary uczenia się" analizując motywację skłaniającą człowieka do podjęcia wysiłku uczenia się (Illeris 2006).

Podsumowując, można stwierdzić, że koncepcja uczenia się osób starszych R. D. Hilla podkreśla wagę tych aspektów uczenia się, które uznane są za bardzo istotne $\mathrm{w}$ andragogicznym, procesualnym modelu uczenia się ludzi dorosłych (Knowles, Holton III, Swanson 2009, s. 107-125).

\section{UCZENIE SIĘ A POZYTYWNE STARZENIE SIĘ}

Związek pozytywnego starzenia się z uczeniem się, zdaniem R. D. Hilla, jest bardzo bliski. W procesie uczenia się, tak samo jak w procesie pozytywnego starzenia się, ważne są cztery zjawiska: mobilizacja źródeł ważnych dla uczenia się, traktowanie uczenia się jako afirmacyjnego wyboru w życiu, kultywowanie elastyczności w uczeniu się oraz skupianie się na pozytywnych wymiarach uczenia się.

Mobilizacja źródeł niezbędnych do uczenia się, związana jest bezpośrednio z uruchomieniem motywacji do uczenia się, na którą składają się:

a) przekonanie, że uczenie się jest możliwe w starszym wieku

b) rozpoznawanie obszarów zainteresowań, które wzbudzą ciekawość poznawczą podmiotu

c) uświadomienie sobie przez podmiot mocnych i słabych stron.

R. D. Hill podkreśla, że przekonanie o tym, że człowiek potrafi się uczyć zapoczątkowuje proces uczenia się. Ważne jest jednak, żeby w starszym wieku dokładnie śledzić przebieg własnego uczenia się i zapisywać postępy w nauce, bo to bardzo motywuje osobę uczącą się.

Uczenie się jako afirmacyjny wybór w życiu daje człowiekowi również silną motywację do uczenia się. Niemniej jednak korzyści z uczenia się mogą pojawić się znacznie później, uczenie prawie zawsze łączy się z uporem 
i cierpliwością. Zawsze, podejmując próbę opanowania nowej umiejętności popełnia się dużo błędów i trzeba radzić sobie z początkowymi niepowodzeniami. Aby utrzymać motywację do uczenia się na odpowiednim poziomie, trzeba traktować decyzję dotyczącą uczenia się jako wybór życiowy. W andragogice znana jest już od dawna kategoria - edukacyjny styl życia, który można porównać z wyborem, jaki proponuje R. D. Hill (Czerniawska 1997).

Kultywowanie elastyczności w uczeniu się również mobilizuje do uczenia się. Zamiast mówić: „Jestem za stary, żeby się uczyć” - osoba starzejąca się pozytywnie, zdaniem R. D. Hilla, stwierdza: „Ponieważ jestem stary, mogę uczyć się czegoś nowego, żeby zachować moje możliwości i utrzymać dobrą kondycję umysłową" (Hill 2008, s. 34).

Skupianie się na pozytywnych wymiarach uczenia się można rozumieć, jak traktowanie uczenia się jako zabawy, ale też działania niezwykle wartościowego. R. D. Hill jest przekonany, że takie afirmacyjne nastawienie umysłu wpływa na motywację człowieka starszego do uczenia się. R. D. Hill wymienia też kilka powodów, dla których osoby starsze angażują się w uczenie się. Są nimi: silniejsze zaangażowanie w relacje z innymi ludźmi, zamiłowanie do uczenia się, ponieważ ono otwiera nowe sposoby myślenia i rozumienia świata, traktowanie uczenia się jako dobrej zabawy, przyjemności, chęć sprostania wyzwaniom, poczucie, że jest się młodszym, walka ze stereotypami dotyczącymi starości (Hill 2008, s. 39).

W edukacji dorosłych od wielu lat znany jest nurt łączenia uczenia się i zabawy, określany nazwą edutainment. ${ }^{5}$ Moim zdaniem takiego między innymi podejścia w uczeniu się dla pozytywnego starzenia się upatruje R. D. Hill.

\section{UCZENIE SIĘ W SYTUACJI CHOROBY I OPIEKI DŁUGOTERMINOWEJ}

Koncepcja pozytywnego starzenia się R. D. Hilla zwraca uwagę też na to, że uczenie się może stanowić strategię pozytywnego starzenia się nawet wtedy, gdy osoba starsza doświadcza spadku sprawności poznawczej i znajduje się w różnych środowiskach życia. Niezależnie od tego czy pozostaje w swoim domu, czy w domu opieki społecznej, bądź innej instytucji opiekuńczej, może nadal się uczyć. R. D. Hill jest wręcz przekonany, że w sytuacji mieszkania w instytucji opiekuńczej, czy leczniczej uczenie się jest tym bardziej potrzebne. Założenie odwrotne, że jest niepotrzebne, bądź niemożliwe jest najbardziej uporczywą formą dyskryminacji ze względu na wiek. Ten stereotyp przeszkadza bowiem w osiąganiu korzyści z idei pozytywnego starzenia

5 Szerzej na ten temat: http://www.edunews.pl/badania-i-debaty/opinie/66. 
się przez osoby, które doświadczają ograniczeń poznawczych i znajdują się w instytucjach opiekuńczych.

Podstawowym argumentem R. D. Hilla, przemawiającym za uczniem się osób starszych z zaburzeniami poznawczymi jest teza, że skoro naucza się osoby młodsze niepełnosprawne intelektualnie, to dlaczego nie zrobić wszystkiego, by zachęcać i umożliwiać osobom starszym z objawami zaburzeń, czy wręcz z demencją, powszechniejsze uczenie się. Zwraca też uwagę na fakt, że ludzi młodych dość często uczy się przez sztukę, a uczenie starszych przez sztukę postrzega się tylko jako wypełnianie ich czasu wolnego, a nie pełnowartościową formę edukacji. R. D. Hill jako psycholog, terapeuta czerpie doświadczenia z własnej praktyki z pacjentami i powołuje się też na badania dotyczące ludzi chorych na Alzheimera. Dla nich uczenie się jest również wartościowym doświadczeniem, ponieważ nadal podtrzymuje zdolności intelektualne, takie jak: ciekawość, kreatywność i inne formy odkrywania świata poprzez zmysły dotyku, czy zapachu. Chorzy uczniowie wymagają jednak nieco innego uczenia się, konkretnych rodzajów terapii z wykorzystaniem różnych rodzajów sztuki i materiałów. Podstawowym celem pracy edukacyjnej z osobami mającymi zaburzenia poznawcze jest, zdaniem R. D. Hilla, stworzenie im warunków i wspomaganie w taki sposób, by mogły żyć aktywnie, na miarę swoich możliwości. W ten sposób u takich uczniów utrzymywane są niepowtarzalne zdolności, które wyróżniały ich kiedyś, we wcześniejszych stadiach życia. Dzięki uczeniu się osoby te pozostają nadal ważne i znaczące (Hill 2008, s. 41-42).

\section{Zakończenie}

Koncepcja pozytywnego starzenia się R. D. Hilla, a w szczególności proponowane przez niego strategie, z pewnością wnoszą do gerontologii społecznej spory wkład. Koncepcja pozytywnego starzenia się, moim zdaniem, wydaje się godna dostrzeżenia i włączenia do grupy innych koncepcji aktywnego starzenia się. Może jednak spotkać się też ze sceptycznym odbiorem, szczególnie za przekonanie na temat możliwości dokonywania indywidualnych wyborów dotyczących własnego starzenia się (Czekanowski, 2012, s. 176). Wartościowe w koncepcji pozytywnego starzenia się jest to, że prezentuje konkretne działania, które mogą kształtować określony, pozytywny stan umysłu oraz poprawiać funkcjonowanie osobiste i społeczne człowieka starszego. Koncepcja ta nie pomija też strat, trudności, chorób i zdarzeń, które mogą wiązać się ze starzeniem się i starością, niemniej jednak próbuje zwró- 
cić uwagę na fakt, że ludzie posiadają wiele zasobów, z których mogą nauczyć się korzystać, by życie stało się lepsze, nawet jeśli zdrowie i sytuacja życiowa się pogarszają.

Coraz częściej w obliczu zmian demograficznych dostrzega się konieczność przygotowania i edukacji do starości zdecydowanie dużo wcześniej, przed nadejściem starości. Problemy starzenia i starości mają wielowymiarowy charakter i oprócz ekonomicznych obaw dotyczących zabezpieczenia finansowego, opiekuńczego, czy medycznego ludzi starszych powinny skupiać się również na humanistycznym podejściu do problemów człowieka w podeszłym wieku. Uczenie się jako strategia pozytywnego starzenia się proponuje takie właśnie podejście, bo chce pomóc podnosić jakość życia osoby starszej.

Uczenie się może stanowić rodzaj aktywnego starzenia się, połączonego z przyjemnością. Tego typu uczenie się jest też próbą włączenia się w nadawanie szerszego znaczenia produktywności społecznej ludzi starszych. Warto też podkreślić, że uczenie się ludzi starszych, które nie pomija osób chorych, niepełnosprawnych nie powoduje wykluczenia społecznego na drodze edukacji. Tak rozumiane aktywne starzenie się nie jest imperatywem, a raczej osobistym wyborem. Uczenie się ludzi starszych może wpływać na podnoszenie produktywności społecznej seniorów w węższym i szerszym ujęciu. Zaradność życiowa, satysfakcja z życia w starości, dłuższa aktywność zawodowa, lepsza kondycja psychofizyczna wpływają bowiem bezpośrednio na mniejsze wydatki związane z opieką, zdrowiem czy sytuacją życiową osób starszych. Uczenie się ludzi starzejących się i starszych ma więc głęboki sens i rozumiane może być bardzo szeroko. Współcześnie szczególną rolę odgrywa w nim nieformalna edukacja, dostosowana do miejsca, oczekiwań i włączająca osoby uczące się w jej planowanie.

Minęły już czasy, w których nie trzeba było myśleć o starości dużo wcześniej. Odwrócona piramida pokoleń wskazuje na konieczność osobistego przygotowania się do starości. Jedną ze strategii może być uczenie się. Konieczność przygotowania własnej starości oddają słowa Jean-Pierre Dubois-Dumée: „Starzenie się to długie lata terminowania, a nawet nowa przygoda. Przygoda głównie duchowa. (...) Trzeba się więc do niej przygotować, ponieważ w pewnym stopniu jest prawdą, że mamy taką starość, na jaką zasłużyliśmy. (...) Starzenie się zaczyna się bardzo wcześnie" (Dubois-Dumée 2004, s. 11). 


\section{Bibliografia}

Aleksander T. (2009), Andragogika. Podręcznik akademicki, Radom-Kraków, Wydawnictwo Naukowe Instytutu Technologii Eksploatacji - Państwowego Instytutu Badawczego, Radom.

Czekanowski P. (2012), Społeczne aspekty starzenia się ludności w Polsce. Perspektywa socjologii starości, Wydawnictwo Uniwersytetu Gdańskiego.

Czerniawska O. (1997), Uczenie się jako styl życia, „Edukacja Dorosłych” nr 2.

Dubois-Dumée J. P. (2004), Starzeć się pięknie, Wydawnictwo Polskiej Prowincji Dominikanów W drodze.

Halicki J. (2006), Społeczne teorie starzenia się [w:] M., Halicka J. Halicki, (red), Zostawić ślad na ziemi, Wydawnictwo Uniwersytetu w Białymstoku, Białystok.

Halicki J. (2008), Potoczne definicje pomyślnego starzenia się, [w:] J. T. Kowaleski, P. Szukalski (red.), Pomyślne starzenie się w perspektywie nauk społecznych i humanistycznych, Zakład Demografii i Gerontologii Społecznej UŁ, Łódź.

Halicki J. (2010), Obrazy starości rysowane przeżyciami seniorów, Wydawnictwo Uniwersytetu w Białymstoku, Białystok.

Hill D., R. (2008), Seven Strategies for positive aging, W.W. Norton@Company, New York.

Hill D., R. (2009), Pozytywne starzenie się. Młodzi duchem w jesieni życia, Wydawnictwo Laurum, Warszawa.

Illeris K., (2006), Trzy wymiary uczenia się. Poznawcze, emocjonalne i społeczne ramy wspótczesnej teorii uczenia się, Wydawnictwo Naukowe Dolnośląskiej Szkoły Wyższej Edukacji TWP, Wrocław.

Knowles M. S., Holton III E. F., Swanson R. A. (2009), Edukacja dorostych. Podręcznik akademicki, Wydawnictwo Naukowe PWN, Warszawa.

Malewski M. (2010), Od nauczania do uczenia się. O paradygmatycznej zmianie $w$ andragogice, Wydawnictwo Naukowe Dolnośląskiej Szkoły wyższej Edukacji TWP, Wrocław.

Matlakiewicz A., Solarczyk-Szwec H. (2009), Dorośli uczq̨ się inaczej. Andragogiczne podstawy kształcenia ustawicznego, Torun, Wydawnictwo Centrum Kształcenia Ustawicznego w Toruniu, Poznań.

Seligman M., E., P. (2011), Pełnia życia. Nowe spojrzenie na kwestię szczęścia i dobrego życia, Media Rodzina.

Seligman M., E., (2005), Prawdziwe szczęście. Psychologia pozytywna a urzeczywistnienie naszych możliwości trwałego spetnienia. Poznań, Media Rodzina.

Seligman, M. E. P., Csikszentmihalyi M. (2000), Positive psychology: An introduction, "American Psychologist", No. 55.

Solarczyk-Ambrozik E. (2009), Kształcenie ustawiczne w perspektywie globalnej i lokalnej. Między wymogami rynku a indywidualnymi strategiami edukacyjnymi, Wydawnictwo Naukowe UAM, Poznań.

WHO: Active Ageing: A Policy Framework World Health Organization, (2002), Geneva. 
Zając-Lamparska L. (2012), Psychologiczne koncepcje pomyślnego starzenia się człowieka, „Rocznik Andragogiczny”, Akademickie Towarzystwo Andragogiczne, Wydawnictwo Naukowe Instytutu Technologii Eksploatacji - Państwowego Instytutu Badawczego, Radom.

\section{Netografia}

Active Ageing: A Policy Framework 2002

http://whqlibdoc.who.int/hq/2002/who_nmh_nph_02.8.pdf (otwarty: 28.12.2013). Błędowski P., 2012, Wprowadzenie. Starzenie się jako problem społeczny. Perspektywy demograficznego starzenia się ludności Polski do roku 2035, [w:] M Mossakowska, A. Więcek, P. Błędowski (red.), Aspekty medyczne, psychologiczne, socjologiczne i ekonomiczne starzenia się ludzi w Polsce, Termedia Wydawnictwa Medyczne, Poznań.

http://polsenior.iimcb.gov.pl/sites/polsenior.iimcb.gov.pl/files/file/monografia/ rodzialy/Wprowadzenie.pdf (otwarty wielokrotnie: 2013).

Szukalski P., 2012, Aktywność zawodowa, [w:] M Mossakowska, A. Więcek, P. Błędowski (red.), Aspekty medyczne, psychologiczne, socjologiczne i ekonomiczne starzenia się ludzi w Polsce, Termedia Wydawnictwa Medyczne, Poznań.

http://212.87.21.2/polsenior/sites/polsenior.iimcb.gov.pl/files/file/monografia/ monografiaPolSenior.pdf (otwarty wielokrotnie: 2013).

Active Ageing Index 2013 http://www1.unece.org/stat/platform/display/AAI/ I.+AAI+in+brief (otwarty: 9.12.2013).

http://www.mpips.gov.pl/aktualnosci-wszystkie/seniorzy/art,6535,nowa-polityka-senioralna-.html (otwarty: 27.12.2013).

WHO Global Report on Falls Prevention In Older Age, 2007.

http://www.google.pl/books?hl=pl\&lr=\&id=ms9o2dvfaQkC\&oi=fnd\&pg=PA1 \&dq=WHO:+Active+Ageing:+A+Policy+Framework + World + Health + Orga nization, + Geneva +2002 .\&ots $=5$ IEZKJRKZW\&sig=51jNtwDbmt_7dDmQ WOhcRQLWKNM\&redir_esc=y\#v=onepage\&q=WHO\%3A\%20Active\%20 Ageing\%3A\%20A\%20Policy\%20Framework\%20World\%20Health\%20 Organization\%2C\%20Geneva\%202002.\&f=false (otwarty: 9.12.2013).

http://www.edunews.pl/badania-i-debaty/opinie/66 (otwarty: 10.12.2013). 